\title{
PENGEMBANGAN SISTEM INFORMASI PENENTUAN MAHASISWA BERPRESTASI MENGGUNAKAN METODE PROMETHEE (STUDI KASUS POLITEKNIK NEGERI MALANG)
}

\author{
Nurcahyo Eko Sumitro ${ }^{1}$, Ridwan Rismanto ${ }^{2}$, Arief Prasetyo ${ }^{3}$ \\ Program Studi Teknik Informatika, Jurusan Teknologi Informasi Politeknik Negeri Malang \\ ${ }^{1}$ nurcahyoes1@gmail.com, ${ }^{2}$ ridwan@ polinema.ac.id, ${ }^{3}$ arief.prasetyo@ polinema.ac.id
}

\begin{abstract}
Abstrak
Pemilihan Mahasiswa Berprestasi merupakan salah satu program Dirjen Dikti yang berguna untuk memilih mahasiswa terbaik dari suatu perguruan tinggi. Mahasiswa yang ikut serta dalam Program Mahasiswa Berprestasi harus memenuhi beberapa kriteria akademis dan kriteria non akademis. Kriteria akademis meliputi Indeks Prestasi Kumulatif, kemampuan berbahasa dan kriteria non - akademis yang meliputi kepribadian, kemampuan berkomunikasi dan kriteria lainnya.

Pada penelitian ini digunakan metode promethee untuk mengurutkan nilai dari beberapa kriteria. Metode ini mampu mengurutkan nilai dari gabungan kriteria kuantitatif seperti jumlah absensi dan kriteria kualitatif seperti nilai IPK, nilai karya tulis, penilaian prestasi, dan kemampuan dalam berbahasa inggris. Kriteria dengan kaidah minimum seperti jumlah absensi dan kriteria dengan kaidah maximum seperti nilai IPK, nilai karya tulis, penilaian prestasi, dan kemampuan dalam berbahasa inggris.

Penelitian ini menghasilkan Sistem Informasi Penentuan Mahasiswa Berprestasi, yang mampu memberikan rekomendasi calon mahasiswa berprestasi dari perhitungan metode promethee.
\end{abstract}

Kata Kunci : Sistem Pendukung Keputusan, mahasaiswa berprestasi, Metode Promethee

\section{Pendahuluan}

Pemilihan Mahasiswa Berprestasi merupakan salah satu program yang berguna untuk memilih mahasiswa terbaik dalam suatu universitas atau perguruan tinggi. Pemilihan mahasiswa berprestasi merupakan salah satu program yang dilaksanakan oleh Dikti sejak tahun 2004. Dalam penyelenggaraannya, pemilihan mahasiswa berprestasi terdiri dari dua kelompok pemilihan, yaitu Mawapres Program Sarjana dan Mawapres Program Diploma.

Politeknik Negeri Malang merupakan salah satu perguruan tinggi negeri di Kota Malang yang rutin melakukan pemilihan mahasiswa berprestasi. Setiap tahun, setiap jurusan yang ada mengirimkan perwakilan untuk mengikuti pemilihan mahasiswa berprestasi tingkat Politeknik Negeri Malang.

Dari keseluruhan peserta yang mengikuti pemilihan akan dilakukan penilaian untuk setiap aspek atau kriteria penilaian dan aturan yang telah ditentukan. Kriteria yang digunakan merupakan kombinasi dari penilaian akademik dan non akademik. Dimana kriteria yang digunakan mengacu pada kriteria yang telah ditentukan oleh Dirjen Dikti, ditambah beberapa penyesuaian yang telah ditetapkan oleh panitia mawapres Politeknik
Negeri Malang. Kriteria tersebut adalah nilai IPK, Karya

Tulis, Prestasi, Kemampuan Bahasa Inggris dan Presensi masing - masing mahasiswa.

Dalam Sistem Pendukung Keputusan terdapat beberapa metode yang dapat digunakan untuk melakukan pengurutan. Salah satu metode yang dapat digunakan adalah metode promethee, metode promethee merupakan satu dari beberapa metode penentuan urutan atau prioritas dalam analisis multikriteria. Metode ini dikenal sebagai metode yang efisien, untuk menuntaskan masalah multikriteria. Metode ini mampu mengakomodir kriteria pemilihan yang bersifat kuantitatif dan kualitatif maupun kriteria yang bersifat minimum dan maksimum.

Berdasarkan penjelasan tersebut, maka dibuatlah suatu sistem informasi yang beguna sebagai pendukung keputusan dalam penentuan mahasiswa berprestasi dengan metode yang digunakan adalah metode promethee.

\section{Landasan Teori}

\subsection{Sistem Informasi}

Sistem Informasi terdiri dari dua kata, yaitu sistem dan informasi. Sistem merupakan kumpulan dari elemen - elemen yang saling berinteraksi 
untuk mencapai tujuan tertentu. Sedangkan informasi merupakan data yang telah diproses menjadi bentuk lain yang memiliki arti bagi penerima dan dapat berupa fakta atau suatu nilai yang bermanfaat. Sehingga sistem informasi merupakan sistem yang saling berhubungan yang berguna mengolah atau memproses suatu data menjadi suatu bentuk yang memiliki nilai manfaat bagi pengguna.

Sistem informasi adalah suatu sistem yang menerima masukan data dan instruksi, mengolah data tersebut sesuai dengan instruksi dan mengeluarkan hasilnya (Davis, 1991:91).

\subsection{Program Mahasiswa Berprestasi}

Program mahasiswa berprestasi merupakan program yang diadakan oleh Dijen Dikti mulai tahun 2014. Program pemilihan mahasiswa berprestasi dilaksanakan setiap tahun, mulai dari tingkat diploma dan tingjat sarjana. Program mahasiswa berprestasi adalah mahasiswa yang berhasil mencapai prestasi tinggi, baik kuriluker, kokurikuler, maupun ekstrakurikuler sesuai dengan kriteria yang ditentukan.

Dalam pelaksanaannya pemilihan mahasiswa berprestasi memiliki tujuan sebagai berikut :

1. Memilih dan memberikan penghargaan kepada mahasiswa yang meraih prestasi tinggi.

2. Memberikan motivasi kepada mahasiswa untuk melaksanakan kegiatan kurikuler, kokurikuler, dan ekstrakurikuler sebagai wahana menyinergikan hard skills dan soft skills mahasiswa.

3. Mendorong perguruan tinggi untuk mengembangkan budaya akademik yang dapat memfasilitasi mahasiswa mencapai prestasi yang membanggakan secara berkesinambungan.

\subsection{Metode Promethee}

Promethee adalah satu dari beberapa metode penentuan urutan atau prioritas dalam analisis multikriteria. Metode ini dikenal sebagai metode yang efisien dan stabil, tetapi juga yang mudah diterapkan dibanding dengan metode lain untuk menuntaskan masalah multikriteria (Arsita, 2013). Metode ini mampu mengakomodir kriteria pemilihan yang bersifat kuantitatif dan kualitatif.

Langkah-langkah perhitungan dengan metode promethee adalah sebagai berikut:

1. Menentukan beberapa alternatif.

2. Menentukan beberapa kriteria.

3. Menentukan dominasi kriteria.

4. Menentukan tipe penilaian, dimana tipe penilaian memiliki 2 tipe yaitu; tipe minimum dan maksimum.
5. Menentukan tipe preferensi untuk setiap kriteria yang paling cocok didasarkan pada data dan pertimbangan dari decision maker. Tipe preferensi ini berjumlah Enam (Usual, Quasi, Linear, Level, Linear Quasi dan Gaussian).

6. Memberikan nilai threshold atau kecenderungan untuk setiap kriteria berdasarkan preferensi yang telah dipilih.

7. Perhitungan Entering flow, Leaving flow dan Net flow.

8. Hasil pengurutan hasil dari perangkingan.

Dalam metode promethee ada 2 macam perangkingan yang disandarkan pada hasil perhitungan, antara lain :

1. Perangkingan parsial yang didasarkan pada nilai Entering flow dan Leaving flow.

2. Perangkingan lengkap atau komplit yang didasarkan pada nilai Net flow.

Dalam metode Promethee ada enam bentuk fungsi preferensi kriteria. Untuk memberikan gambaran yang lebih baik terhadap area yang tidak sama, maka digunakan tipe fungsi preferensi. Keenam tipe preferensi tersebut meliputi:

1. Kriteria Usual

$$
\begin{gathered}
H(d)=\left\{\begin{array}{l}
0 \text { jika } d \leq 0 \\
1 \text { jika } d>0
\end{array}\right. \\
\text { Dimana : }
\end{gathered}
$$

$\mathrm{H}(\mathrm{d})=$ fungsi selisih kriteria antar alternatif

$$
\mathrm{d}=\text { selisih nilai kriteria }\{\mathrm{d}=\mathrm{f}(\mathrm{a}) \text { - }
$$

f(b) $\}$

Merupakan fungsi preferensi yang cocok untuk kriteria kualitatif atau mutu, misalnya nilai dsb. Funsi kriteria ini digunakan untuk kriteria dengan skala kecil, misalnya ya atau tidak, atau skala 1 sampai 5.

2. Kriteria Quasi (Quasi Criterion / U-Shape)

$$
\begin{gathered}
H(d)=\left\{\begin{array}{l}
0 \text { jika } d \leq q \\
1 \text { jika } d>q
\end{array}\right. \\
\text { Dimana : }
\end{gathered}
$$

$$
\mathrm{H}(\mathrm{d})=\text { fungsi selisih kriteria antar }
$$
alternatif

$$
\mathrm{d}=\text { selisih nilai kriteria }\{\mathrm{d}=\mathrm{f}(\mathrm{a}) \text { - }
$$

f(b) \}

$\mathrm{q}=$ harus merupakan nilai tetap 
Fungsi Quasi sama seperi fungsi kriteria usual, bedanya fungsi kriteria quasi lebih spesial dari fungsi kriteria usual.

3. Kriteria Linier (Linier Criterion / V-Shape)

$$
H(d)=\left\{\begin{array}{c}
0 \text { jika } d \leq 0 \\
d / p \text { jika } 0 \leq d \leq p \\
1 \text { jika } d>p
\end{array}\right.
$$

Dimana :

$\mathrm{H}(\mathrm{d})$ = fungsi selisih kriteria antar alternative

$$
\mathrm{d}=\text { selisih nilai kriteria }\{\mathrm{d}=\mathrm{f}(\mathrm{a}) \text { - }
$$

f(b) $\}$

$$
\mathrm{p}=\text { nilai kecenderungan atas }
$$

Merupakan fungsi preferensi yang cocok untuk kriteria kuantitatif atau mementingkan jumlah, misalnya harga, biaya dan sebagainya.

\section{Kriteria Level (Level Criterion)}

$$
\begin{aligned}
& H(d)=\left\{\begin{array}{c}
0 \text { jika } d \leq q \\
0,5 \text { jika } q<d \leq p \\
1 \text { jika } d>p
\end{array}\right. \\
& \text { Dimana : } \\
& \mathrm{H}(\mathrm{d})=\text { fungsi selisih kriteria antar }
\end{aligned}
$$
alternatif

$$
\mathrm{d}=\text { selisih nilai kriteria }\{\mathrm{d}=\mathrm{f}(\mathrm{a}) \text { - }
$$

f(b) $\}$

$$
\begin{aligned}
& \mathrm{p}=\text { nilai kecenderungan atas } \\
& \mathrm{q}=\text { harus merupakan nilai tetap }
\end{aligned}
$$

Merupakan tipe preferensi yang cocok digunakan untuk tipe kriteria kualitatif atau mutu. Berbeda dengan tipe kriteria quasi, kritria level cenderung digunakan untuk kriteria dengan skala yang cukup besar.

5. Kriteria dengan Preferensi Linier dan Area yang Tidak Berbeda (Criterion with linier preference and indifference area)

$$
H(d)=\left\{\begin{aligned}
0 \text { jika } d & \leq q \\
\frac{d-q}{p-q} \text { jika } q<d \leq p & <\text { jika } d>p
\end{aligned}\right.
$$

$$
\text { Dimana : }
$$

$\mathrm{H}(\mathrm{d})$ = fungsi selisih kriteria antar alternatif

$\mathrm{d}=$ selisih nilai kriteria $\{\mathrm{d}=\mathrm{f}(\mathrm{a})-\mathrm{f}(\mathrm{b})\}$

$$
\mathrm{p}=\text { nilai kecenderungan atas }
$$

$$
\mathrm{q}=\text { harus merupakan nilai tetap }
$$

Merupakan fungsi preferensi untuk kriteria kuantitatif atau banyaknya jumlah

\section{Kriteria Gaussian (Gaussian Criterion)}

$$
H(d)=\left\{\begin{array}{c}
0 \text { jika } d \leq 0 \\
1-e-\frac{d^{2}}{2 a^{2}} \text { jika } d>0
\end{array}\right.
$$

Dimana :

$$
\mathrm{H}(\mathrm{d})=\text { fungsi selisih kriteria antar }
$$
alternatif

$$
\mathrm{d}=\text { selisih nilai kriteria }\{\mathrm{d}=\mathrm{f}(\mathrm{a}) \text { - }
$$

f(b) $\}$

Tipe Gaussian sering digunakan pada data yang bersifat continue atau berjalan terus. Nilai kecenderungan atau threshold sendiri yaitu s, nilainya berada diantara nilai $\mathrm{q}$ dan $\mathrm{p}$.

Dalam metode promethee terdapat arah preferensi yang dipertimbangkan berdasarkan nilai indeks perangkingan antara lain :

1. Entering flow

Entering flow adalah jumlah dari yang memiliki arah mendekat dari node a dan hal ini merupakan karakter pengukuran outrangking. Untuk setiap nilai node a dalam grafik nilai outrangking ditentukan berdasarkan entering flow seperti terlihat pada persamaan 3.7

$\varphi^{-}(a)=\frac{1}{n-1} \sum_{x \in A} \varphi(\mathrm{a}, \mathrm{x})$

2. Leaving flow

Sedangkan leaving flow adalah jumlah dari yang memiliki arah menjauh dari node a. Dan hal ini merupakan pengukuran outrangking. Adapun persamaannya terlihat seperti pada persamaan 3.8.

$\varphi^{+}(a)=\frac{1}{n-1} \sum_{x \in A} \varphi(\mathrm{a}, \mathrm{x})$

3. Net flow

Sehingga pertimbangan dalam penentuan Net flow diperoleh dengan persamaan seperti terlihat pada persamaan 3.9 .

$\varphi(a)=\varphi^{+}(a)-\varphi^{-}(a)$

\section{Metodologi Penelitian}

\subsection{Metode Pengumpulan Data}

Untuk dapat melakukan analisis yang baik, diperlukan data, serta teori konsep dasar, sehingga 
kebutuhan data sangat mutlak diperlukan. Adapun metode pengumpulan data dilakukan dengan cara :

a. Wawancara

Wawancara merupakan metode yang digunakan untuk memperoleh keterangan untuk tujuan penelitian dengan cara tanya jawab, Pada skripsi penentuan mahasiswa berprestasi terdapat pihak yang dilakukan wawancara yaitu

1. Bagian Akademik Politeknik Negeri Malang

2. Bagian PSI Politeknik Negeri Malang

b. Dokumentasi

Pengambilan data melalui dokumen tertulis maupun elektronik dari lembaga atau institusi. Dokumen tersebut berguna untuk mendukung kelengkapan data yang lain.

\subsection{Metode Pengujian}

Black-box testing merupakan sutau pengujian yang berfokus pada spesifikasi fungsional dari perangkat lunak, Black-box testing merupakan pengujian yang dilakukan tanpa mengetahi apa yang terjadi di dalam sistem (hanya masukan dan inputan).

Perancangan pengujian dilakukan dengan melakukan masukan yang valid maupun melakukan masukan yang tidak valid dan menentukan hasil yang benar. Metode uji dapat diterapkan pada semua tingkat pengujian perangkat lunak: unit, integrasi, fungsional, sistem dan penerimaan.

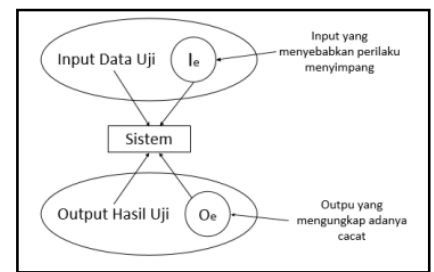

Gambar 1 Model pengujian Black-box

(Sommerville, 2003:87)

\section{Analisa dan Perancangan}

\subsection{Pengguna}

Dalam pengembangan sistem informasi penentuan mahasiswa berprestasi terdapat tiga pengguna yaitu admin, penilai, dan pengunjung, dimana setiap pengguna memiliki hak akses masing - masing.

- Admin

Admin atau administrator merupakan user yang memiliki hak akses penuh terhadap sistem admin.

- Penilai

Penilai merupakan user yang memiliki hak akses untuk mengelola data nilai ke sistem.

- Pengunjung
Merupakan user yang memiliki hak akses melihat hasil perhitungan pada halaman pengunjung.

\subsection{Use case Diagram}

Use case diagram ialah model fungsional sebuah sistem yang menggunakan actor dan use case. Use case adalah layanan (services) atau fungsi-fungsi yang disediakan oleh sistem untuk penggunanya (Henderi et al, 2008). Use case digunakan untuk mengetahui siapa yang terlibat dan apa yang dapat dilakukan didalam sistem.

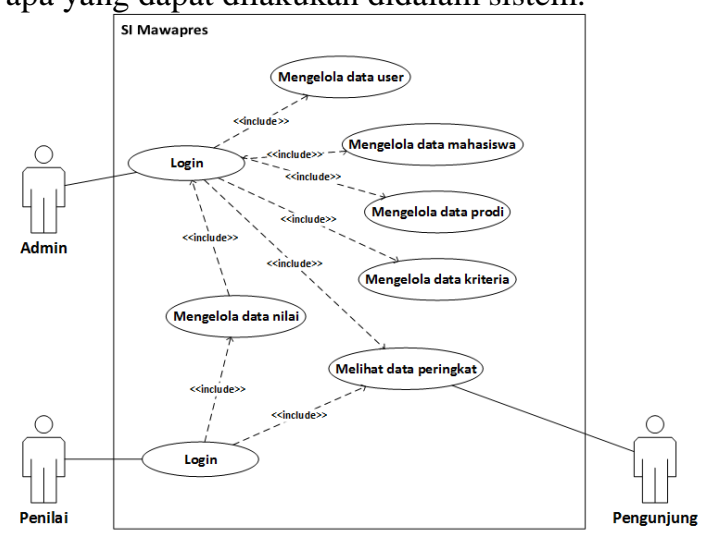

Gambar 2 Use case diagram

5. Implementasi

\subsection{Implementasi Basis Data}

Pada sub bab implementasi basis data akan dijelaskan mengenai penerapan dari basis data yang digunakan pada sistem. Berdasarkan perancangan yang telah dilakukan, dibuat database yang bernama mawapres yang berisi beberapa tabel, seperti terlihat pada gambar 4.1

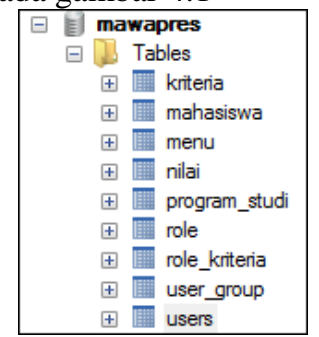

Gambar 3 Implementasi basis data

\subsection{Implementasi Sistem}

Pada implementasi sistem akan dijabarakan implementasi dari sistem penentuan mahasiswa berprestasi.

\subsubsection{Implementasi Halaman Pengunjung}

Halaman pengunjung merupakan halaman yang pertama kali ditampilkan saat pengguna mengakses aplikasi. Implementasi halaman pengunjung dapat dilihat pada Gambar 5 


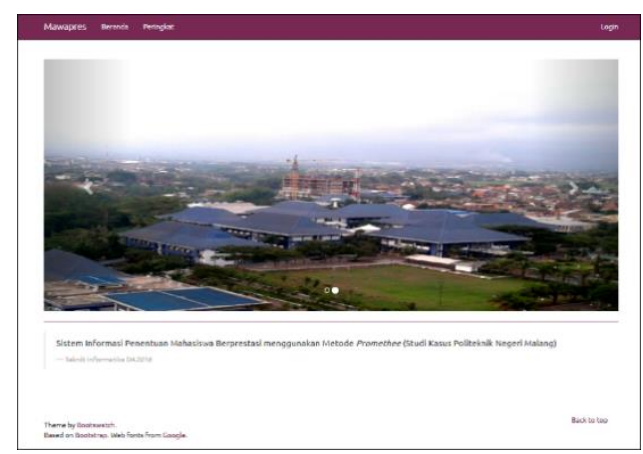

Gambar 5 Implementasi halaman pengunjung

\subsubsection{Implemetasi Halaman Admin}

Halaman admin adalah halaman pertama yang ditampilkan jika user berhasil login sebagai administrator. Pada halaman ini terdapat menu admin, data detail admin. Implementasi halaman beranda dapat dilihat pada Gambar 6
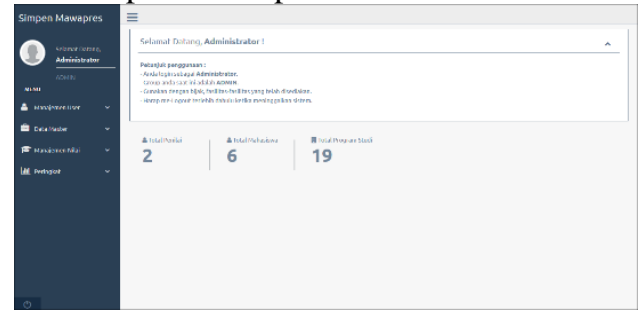

Gambar 6 Implementasi halaman admin

\subsubsection{Implementasi Halaman Penilai}

Halaman beranda penilai merupakan halaman yang pertama kali ditampilkan setelah user penilai berhasil masuk ke aplikasi. Implementasi halaman beranda penilai terlihat pada Gambar 7
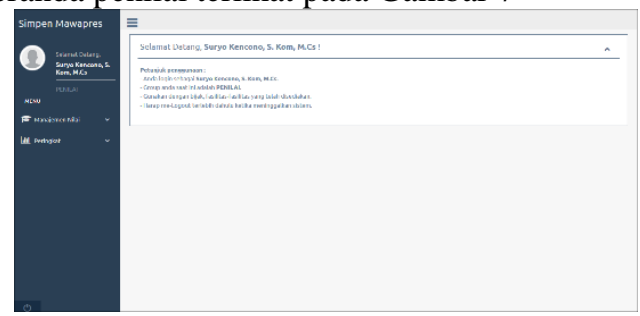

Gambar 7 Implementasi halaman penilai

\section{Pengujian dan Pembahasan}

Pengujian validasi perhitungan berguna untuk menguji perhitungan, baik perhitungan manual maupun perhitungan dari sistem pada penentuan mahasiswa berprestasi.

\subsection{Pengujian Perhitungan Manual}

Perhitungan manual metode promethee dilakukan dengan menggunakan data kriteria yang sudah ditentukan sebelumnya., data kriteria tersebut adalah IPK, Karya Tulis, Prestasi, Bahasa Inggris dan Presensi. Dan data alternatif atau mahasiswa yang digunakan adalah enam mahasiswa, seperti terlihat pada Tabel 1 .
Tabel 1 Menentukan alternatif dengan nilai

\begin{tabular}{|l|r|r|r|r|r|}
\hline \multirow{2}{*}{ Kriteria } & \multicolumn{5}{|c|}{ Alternatif } \\
\cline { 2 - 6 } & \multicolumn{1}{c|}{$\mathrm{A}$} & \multicolumn{1}{c|}{$\mathrm{B}$} & \multicolumn{1}{c|}{ C } & \multicolumn{1}{c|}{ D } & \multicolumn{1}{c|}{ E } \\
\hline IPK & 3,64 & 3,72 & 3,80 & 3,83 & 3,75 \\
\hline Karya Tulis & 1237,50 & 1275,00 & 1200,00 & 0 & 1265,0 \\
\hline Prestasi & 84,00 & 70,00 & 70,00 & 80,00 & 85,00 \\
\hline Bhs. Inggris & 147,50 & 140,00 & 127,50 & 156,50 & 152,00 \\
\hline Presensi & 0 & 0 & 0 & 0 & 0 \\
\hline
\end{tabular}

\begin{tabular}{|l|r|r|r|r|r|}
\hline \multirow{2}{*}{ Kriteria } & \multicolumn{5}{|c|}{ Alternatif } \\
\cline { 2 - 6 } & \multicolumn{1}{c|}{$\mathrm{F}$} & \multicolumn{1}{c|}{$\mathrm{G}$} & \multicolumn{1}{c|}{$\mathrm{H}$} & \multicolumn{1}{c|}{ I } & \multicolumn{1}{c|}{ J } \\
\hline IPK & 3,54 & 3,71 & 3,75 & 3,85 & 3,75 \\
\hline Karya Tulis & 1145,00 & 1200,00 & 1170,00 & 1365,00 & 1210,00 \\
\hline Prestasi & 70,00 & 82,00 & 82,00 & 80,00 & 80,00 \\
\hline Bhs. Inggris & 112,00 & 114,00 & 114,00 & 126,00 & 122,00 \\
\hline Presensi & 0 & 0 & 0 & 0 & 0 \\
\hline
\end{tabular}

Pada Tabel 2 merupakan tabel bobot masing masing kriteria. Data bobot jika dijumlahkan adalah 1 .

Tabel 2 Penentuan Bobot

\begin{tabular}{|l|l|}
\hline Kriteria & Bobot \\
\hline IPK & 0,2 \\
\hline Karya Tulis & 0,3 \\
\hline Prestasi & 0,3 \\
\hline B. Inggris & 0,1 \\
\hline Presensi & 0,1 \\
\hline
\end{tabular}

Setelah menetukan bobot kriteria, dilakukan perhitungan pembobotan, dengan cara mengkalikan nilai dengan bobot. Selanjutnya dilakukan penentuan tipe penilaian, tipe penilaian dapat berupa maksimal atau minimal. Dan juga dilakukan penentuan tipe preferensi kriteria sesuai dengan data yang ada, seperti Tabel 3

Tabel 3 Penentuan tipe penilaian dan tipe kriteria

\begin{tabular}{|l|l|l|}
\hline Kriteria & Bobot & Tipe \\
\hline IPK & 0,2 & Quasi \\
\hline K. Tulis & 0,3 & Level \\
\hline Prestasi & 0,3 & Level \\
\hline B. Inggris & 0,1 & Level \\
\hline Presensi & 0,1 & V-Shape \\
\hline
\end{tabular}

Kemudian dilakukan perhitungan untuk menentukan nilai threshold dari masing - masing kriteria. Threshold terdiri dari dua macam yaitu $q$ dan $p$. Nilai threshold $q$ merupakan indifferent threshold sedangkan threshold $p$ merupakan preference threshold.

Rumus :

$$
\begin{gathered}
q=\frac{\left(\max \left(X_{i}, X_{j}\right)-\min \left(X_{i}, X_{j}\right)\right)}{2} \\
p=\max \left(X_{i}, X_{j}\right)^{2}-\min \left(X_{i}, X_{j}\right)
\end{gathered}
$$


Tabel 4 Threshold kriteria

\begin{tabular}{|c|c|c|}
\hline \multirow{2}{*}{ Kriteria } & \multicolumn{2}{|c|}{ Parameter } \\
\cline { 2 - 3 } & $\mathrm{q}$ & $\mathrm{p}$ \\
\hline IPK & 0,031 & 0,062 \\
\hline Karya Tulis & 58,500 & 117,000 \\
\hline Prestasi & 2,250 & 4,500 \\
\hline Bahasa Inggris & 2,225 & 4,450 \\
\hline Absensi & 0,000 & 0,000 \\
\hline
\end{tabular}

Langkah selanjutnya adalah menghitung indeks preferensi kriteria, pada perhitungan ini dilakukan perbadingan nilai antar alternatif di setiap kriteria. Proses perbandingan terlihat seperti Gambar 8

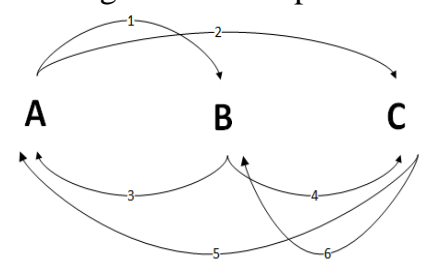

Gambar 8 Membandingkan nilai alternatif

Proses menghitung nilai indeks preferensi kriteria dilakukan dengan menghitung selisih antar dua alternatif (d). Kemudian nilai selisih tersebut akan dijadikan kunci untuk menghitung nilai fungsi selisih kriteria antar alternatif $\mathrm{H}(\mathrm{d})$. Nilai $\mathrm{H}(\mathrm{d})$ diperoleh dar perhitunagn sesuai tipe referensi kriteria yang ditentukan sebelumnya.

Selanjutnya dilakukan penjumlahan sesuai indeks perbandingan dari seluruh kriteria. Kemudian nilai tersebut dimasukkan ke dalam tabel indeks preferensi multi kriteria seperti terlihat pada Tabel 5

Tabel 5 Tabel indeks preferensi multikriteria

\begin{tabular}{|l|l|l|l|l|l|l|l|l|l|l|}
\hline & a & b & c & d & e & f & g & h & i & j \\
\hline a & 0,00 & 0,50 & 0,50 & 0,00 & 0,00 & 1,00 & 0,50 & 0,50 & 0,00 & 0,50 \\
\hline b & 0,00 & 0,00 & 0,00 & 0,00 & 0,00 & 1,50 & 0,50 & 0,50 & 0,00 & 0,00 \\
\hline c & 1,00 & 0,00 & 0,00 & 0,00 & 0,00 & 1,00 & 0,00 & 0,00 & 0,00 & 0,00 \\
\hline d & 1,50 & 1,00 & 1,50 & 0,00 & 0,50 & 2,50 & 1,00 & 1,00 & 0,50 & 1,00 \\
\hline e & 0,00 & 0,50 & 1,00 & 0,00 & 0,00 & 2,00 & 0,50 & 0,50 & 0,50 & 0,50 \\
\hline f & 0,00 & 0,00 & 0,00 & 0,00 & 0,00 & 0,00 & 0,00 & 0,00 & 0,00 & 0,00 \\
\hline g & 0,00 & 0,50 & 0,50 & 0,00 & 0,00 & 1,50 & 0,00 & 0,00 & 0,00 & 0,00 \\
\hline h & 0,00 & 0,50 & 0,50 & 0,00 & 0,00 & 1,50 & 0,00 & 0,00 & 0,00 & 0,00 \\
\hline i & 1,00 & 0,50 & 0,50 & 0,00 & 0,00 & $\mathbf{2 , 0 0}$ & 0,00 & 0,00 & 0,00 & 0,00 \\
\hline j & 0,00 & 0,50 & 0,50 & 0,00 & 0,00 & 1,50 & 0,00 & 0,00 & 0,00 & 0,00 \\
\hline
\end{tabular}

Langkah selanjutnya dilakukan proses perhitungan promethee I dan promethee II. Pada promethee I terdiri dari perhitungan leaving flow dan entering flow. Berikut merupakan perhitungan dengan mengambil contoh alternatif a.

$$
\begin{aligned}
& \text { Leaving flow } \\
& \varphi^{+}=\frac{1}{6-1} *(0+1,5+0+0+0,5+1,5)=\frac{1}{5} * 3,5=0,7 \\
& \text { - } \quad \text { Entering flow } \\
& \varphi^{-}=\frac{1}{6-1} *(0+0+1,5+1+1+1)=\frac{1}{5} * 4,5=0,9 \\
& \text { - Net flow } \\
& \quad a=0,7-0,9=-0,2
\end{aligned}
$$

Tabel 6 Hasil perhitungan promethee

\begin{tabular}{|c|c|c|c|}
\hline Alternatif & Leaving & Entering & Net \\
\hline A & 0,388888889 & 0,388888889 & 0 \\
\hline B & 0,277777778 & 0,444444444 & $-0,166666667$ \\
\hline C & 0,222222222 & 0,555555556 & $-0,333333333$ \\
\hline D & 1,166666667 & 0 & 1,166666667 \\
\hline E & 0,611111111 & 0,055555556 & 0,555555556 \\
\hline F & 0 & 1,611111111 & $-1,611111111$ \\
\hline G & 0,277777778 & 0,277777778 & 0 \\
\hline H & 0,277777778 & 0,277777778 & 0 \\
\hline I & 0,444444444 & 0,111111111 & 0,333333333 \\
\hline J & 0,277777778 & 0,222222222 & 0,055555556 \\
\hline
\end{tabular}

\subsection{Pengujian Perhitungan Sistem}

Pada sub bab pengujian perhitungan sistem digunakan untuk menguji sistem yang telah dibuat. Langkah - langkah pengujian dilakukan dengan menambah data kriteria, menambah data alternatif atau mahasiswa, dan memasukkan nilai. Hasil dari perhitungan promethee terlihat pada Gambar 7

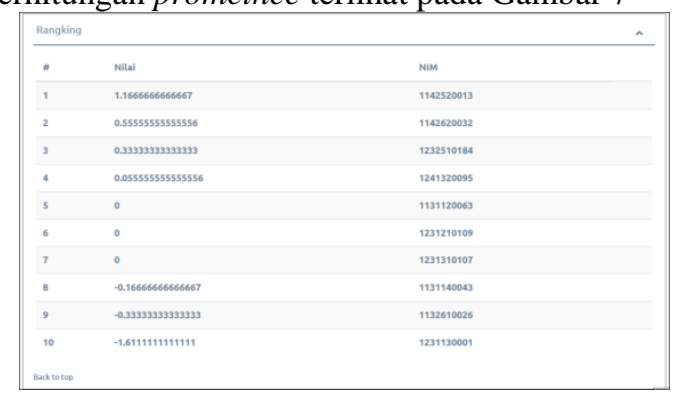

Gambar 7 Hasil perhitungan system

\section{Pembahasan Hasil}

Pembahasan hasil dilakukan untuk membandingkan hasil yang dilakukan perhitungan manual dengan perhitungan oleh sistem yang dibuat. Pada Tabel 8 merupakan perbandingan hasil perhitungan manual dengan perhitungan sistem.

Tabel 8 Perbandingan hasil perhitungan

\begin{tabular}{|c|c|c|c|c|}
\hline \multirow{2}{*}{ Nama } & \multicolumn{2}{|c|}{ Hasil Perhitungan } & \multirow{2}{*}{ Error } & $\begin{array}{c}\text { Persentase } \\
\text { Error }\end{array}$ \\
\cline { 2 - 3 } & Manual & Sistem & & $0 \%$ \\
\hline Vikri Rahmat S & 0 & 0 & 0,0 & $0 \%$ \\
\hline Rakha S. & $-0,16667$ & $-0,16667$ & 0,0 & $0 \%$ \\
\hline Lutfiyyatul A. & $-0,33333$ & $-0,33333$ & 0,0 & $0 \%$ \\
\hline Desy N. & 1,16667 & 1,16667 & 0,0 & $0 \%$ \\
\hline Sonia Izzati & 0,55556 & 0,55556 & 0,0 & $0 \%$ \\
\hline Riznatul N.A. & $-1,61111$ & $-1,61111$ & 0,0 & $0 \%$ \\
\hline Edho Nara L. & 0 & 0 & 0,0 & $0 \%$ \\
\hline Sabra El Satilah & 0 & 0 & 0,0 & $0 \%$ \\
\hline Hafidatun Nisa' & 0,33333 & 0,33333 & 0,0 & $0 \%$ \\
\hline Cintri Anjani R. & 0,05556 & 0,05556 & 0,0 & $0 \%$ \\
\hline
\end{tabular}

Pada Tabel 8 terlihat perbandingan antara perhitungan manual dan perhitungan yang dilakukan oleh sistem. Pada tabel juga ditampilkan jarak kesalahan / error beserta persentase error. Dari tabel 8 terlihat bahwa implementasi penentuan mahasiswa berprestasi menggunakan metode promethee pada sistem menghasilkan nilai yang sama seperti perhitungan manual. 


\section{Kesimpulan dan Saran \\ 8.1 Kesimpulan}

Berdasarkan penelitian yang dilakukan dapat diambil kesimpulan sebagai berikut

1. Penerapan metode promethee menghasilkan rekomendasi calon mahasiswa berprestasi.

2. Sistem informasi pengembangan penentuan informasi menggunakan metode promethee telah dibuat dapat berjalan dengan baik secara fungsional dan menghasilkan keluaran yang sesuai harapan.

3. Metode promethee dapat menerapkan tipe preferensi kriteria dan kaidah pada kriteria yang digunakan pada penentuan mahasiswa berprestasi. Perhitungan metode promethee dihasilkan dengan membandingkan nilai antar alternatif, dan menghitung dominasi alternatif sesuai threshold yang telah ditentukan pada setiap tipe preferensi kriteria. Dominasi alternatif selanjutnya digunakan untuk perumusan dalam perhitungan peringkat.

4. Metode promethee menghasilkan pemeringkatan yang lebih efektif dengan mengambil kelebihan serta kelemahan setiap alternatif dari alternatif lain berdasarkan nilai yang diperoleh..

\subsection{Saran}

Adapun saran untuk aplikasi kedepannya adalah

1. Sistem informasi penentuan mahasiswa berprestasi ini perlu ditambahkan metode lain, sehingga dapat digunakan sebagai perbandingan hasil dari metode promethee.

\section{Daftar Pustaka}

Arsita, Reizha., 2013. "Sistem Pendukung Keputusan Penerima Jaminan Kesehatan Masyarakat (JAMKESMAS) dengan Metode Promethee (Studi Kasus : Tegal Sari Mandala - I)". Pelita Informatika Budi Darma. 4(2), 106-114

Booch G., Maksimchuk R.A., Engle M.W., Young, B.J., Conallen J., and Houston K.A., 2007 ,Object Oriented Analysis and Design with Applications Third Edition. Addison Wesley, USA.

Davis, B. Gordon., 1991. Kerangka Dasar Sistem Informasi Manajemen Bagian 1. Jakarta: Pustaka Binamas Pressindo

Dimas., 2013. Pengertian SI (SISTEM INFORMASI). [Online] Tersedia : http://www.kompasiana.com/dimasosd/peng ertian-si-sistem-informasi 55291077f17e61 26268b48b6[4 Januari 2016]
Hanifah, Riska., 2015., "Implementasi Metode Promethee Dalam Penentuan Penerima Kredit Usaha Rakyat (KUR)”. Jurnal Teknologi IKPIA Perbanas. 8(2), 169-177

Harsono, Ambar., 2009., "Metode Pemilihan Pemasok Sayuran di Supermarket dengan Metode AHP dan PROMETHEE (Studi kasus di PT. Hero Supermarket Cabang Suci Bandung)". Jurnal Itenasi Rekayasa Institut Teknologi Nasional. 13(4), 184-195

Henderi., et all., 2008. Unified Modeling Language (UML): Konsep dan Implementasinya Pada Pemodelan Sistem Berorientasi Objek dan Visual (Buku I). Tangerang:STMIK Raharja

Huda, Khoirul., 2011., Sistem Pendukung Keputusan untuk Penentuan Beasiswa Bagi Mahasiswa Berprestasi Menggunakan Metode Promethee. Program studi teknik informatika : Laporan Akhir tidak diterbitkan.

Iwan., 2013., Pengertian Sistem Informasi Menurut Para Ahli Definisi. [Online] Tersedia : http://fisipuin.satugen.com/blog/PengertianSistem-Informasi-Menurut-Para-AhliDefinisi [4 Desember 2016]

Lemantara, J., et all., 2013. "Rancang Bangun Sistem Pendukung Keputusan Pemilihan Mahasiswa Berprestasi Menggunakan Metode AHP dan Promethee". JNTETI. 2(4), 20-28

Munawar., 2005. Pemodelan Visual Menggunakan UML. Jogjakarta:Graha Ilmu

Pedoman Pemilihan Mahasiswa Berprestasi Program Diploma. 2015. Tersedia : http://mawapres.dikti.go.id/file/pendukung/2 015/PANDUAN\%20MAWAPRES\%20DIP LOMA\%202015.pdf [6 November 2015]

Sommerville, Ian., 2003. Software Engineering: Rekayasa Perangkat Lunak (Jilid 2) (Edisi 6). Jakarta : Erlangga

Sutanta., 2003. Sistem Pendukung Keputusan (Decision Support System). [Online] Tersedia : http://is.its-sby.edu/subjects/dss/ Buku_Panduan_SPK.pdf [5 Desember 2015] 